\title{
Promoting Creativity and Innovation in Initial Teacher Technical Education in Ireland: A Case Study
}

\section{Logue, Pauline Anne}

Galway Mayo Institute of Technology, Ireland.

\begin{abstract}
The Galway-Mayo Institute of Technology (GMIT), Ireland, is a Higher Education (HE) provider of Initial Teacher Education (ITE). Graduates on its BSc (Hons) in Education (Design, Graphics and Construction) degree programme are qualified to teach technical subjects at second level. A defining element of delivery is the promotion of creativity and innovation in the classroom, by means of active, student-centred and design-led teaching and learning $(T \& L)$ strategies. This paper outlines a GMIT qualitative student-perspective pilot study, involving GMIT student teacher participants $(n=42)$. The study aims to analyse the effectiveness of two selected platforms in the ITE programme: 1) presentation contributions by student teachers at the GMIT 'Creativity and Innovation in Teaching' Conference (2016) $(n=14)$, and 2) a textual analysis of student online forum critical reflection submissions (2016-2017) ( $n=28)$. The research confirms the effectiveness of both strategies in promoting a practice of innovation and creativity in the classroom, including evidence of innovation, formative instructional practices and student-centred, active learning and design-led strategies in $T \& L$. Challenges identified include classroom management and time management constraints.
\end{abstract}

Keywords: Creativity, Innovation, Educational Technology, Technical Education, Initial Teacher Education, Active teaching Strategies. 


\section{Introduction}

The Galway-Mayo Institute of Technology (GMIT) is a Higher Education (HE) provider of Initial Teacher Education (ITE) in the technical field, in Ireland. Graduates on its $B S c$ (Hons) in Education (Design, Graphics and Construction) degree programme are qualified to teach select technical subject areas at second level. A defining element of programme ethos and delivery is the promotion of creativity and innovation in the classroom. In February 2016, GMIT held a conference event, entitled, 'Creativity and Innovation in the Classroom', featuring best practice innovations by final year student teachers. In that same academic year student teachers also engaged in online forum critical reflections (using the Moodle platform) relating to their practice of teaching while on School Placement (SP). These two platforms were used to collate research data for this study. The research question addressed in this paper is: "to what extent do GMIT student teachers demonstrate creativity and innovation in their T\&L strategies, in the technical classroom, while on School Placement?". The two main research aims addressed in this paper include: 1) to identify/tabulate evidence of creative and innovative practices while on SP, and 2) to explore the student teacher experience of engagement with creative and innovative teaching practices, using selected examples from the data. Primary and secondary research methods are employed. Regarding the structure of the paper, a brief literature review is followed by accounts of the research methodology, findings, analysis, and conclusions.

\section{Literature Review}

The European Commission highlights the necessity to promote high quality $\mathrm{T} \& \mathrm{~L}$ in European HEs (The European Commission 2013, p. 19). This expectation is reinforced by the Department of Education, the Higher Education Authority (HEA), the National Forum for Teaching and Learning, the Teaching Council (TC) and the National Council for Curriculum and Assessment (NCCA), Ireland. GMIT's current Strategic Plan (2013) seeks to promote best practice and innovation in T\&L. In the GMIT ITE programme, a culture of creativity and innovation, as well as active, student-centred and design-led T\&L, is upheld, however, a challenge arising is the disjunction between a policy of student-centred active $\mathrm{T} \& \mathrm{~L}$ in $\mathrm{HE}$ and a traditional, didactic approach, which is prevalent in many second level schools. This is a subject of discussion and debate in the Irish media in recent years (Flynn, 2012; Gleeson, 2013; Renville, 2015). In the 2007 publication Active Learning and Teaching Methods for Key Stage 3, the argument in favour of active teaching strategies is made that "young people need to have opportunities to develop personal capabilities and effective thinking skills as part of their well-rounded education (The Partnership Management Board, 2007, p. 1). 
Approaches to creative, innovative and active student-centred learning promoted in the GMIT ITE programme include, among others: promoting problem solving strategies (Humphreys, 1996), facilitating student teachers to embrace change in the context of a rapidly evolving Teacher Education (TE) landscape (Quinn et al. 2014), training in Problem-based Learning (Barrett and Moore, 2011), explorations of and critical reflection on strategies for Design-led Learning (Owen-Jackson, 2015), engagement in a variety of Peer Observation, Teaching and Review processes (Klopper \& Drew, 2015), and researchbased teaching, learning and assessment (Cohen et al. 2000).

\section{Research Methodology}

This student-perspective study employed a qualitative research methodology. A total of forty- two student teachers were included in the study. Data collecting methods included: 1) the identification and tabulation of innovative practices employed by final year student teachers $(n=14)$ while on SP, as recorded by the GMIT Creativity and Innovation in the Classroom Conference (2016) presentation slides, and 2) the identification of innovative or creative approaches by other students across the wider programme $(n=28)$, identified within their SP online forum critical reflections (2016-2017). These two data sets are referred to as Data Set 1 and Data Set 2, respectively, in this study. Data Set 1 consisted of the conference presentation content, captured in the form of audio-visual recordings of the presentation and presentations slides content, and Data Set 2 was in the form of written forum reflection transcripts. These data sources were collated by the SP module leader (author of this paper). With respect to ethics, in particular research consent, in the case of Data Set 1 , the conference event was live streamed, hence in the public forum, by prior agreement with all parties. In the case of Data Set 2 students were informed of the research via GMIT Learnonline and given an e mail 'opt out' option.

\section{Research Findings, Analysis \& Discussion}

Research AIM 1 was to identify/tabulate evidence of innovative practices across the ITE programme. Using a method of manual coding of the data transcripts, illustrative examples were identified in student teacher practices, following repeated readings and re-readings of the transcript materials. Beginning with data set 1 , the 'Creativity and Innovation in the Classroom Conference' presentation slides (2016) provided evidence of the use of a broad selection of creative, innovative, active, and design-led T\&L practices on the part of the final year student-teacher presenters $(n=14)$ while on SP. Evidence examples are tabulated below according to the dominant recurring categories of: 1) creativity and innovation $T \& L$ strategies, 2) active, student-centred T\&L strategies, and 3) design-led T\&L strategies. 
Some student teachers $(n=4)$ discussed a combined approach, incorporating more than one example of creativity and innovation, hence the number of examples provided in the cells in Table 1 (below) totals 18. Within the overall data, a balance of teaching examples across these three categories or themes were identified, demonstrating a comprehensive set of innovative and creative SP teaching tools and strategies.

Table 1. Data Set 1: Creativity and Innovation in the Classroom Conference 2016

\begin{tabular}{|c|c|c|}
\hline Creativity \& Innovation & $\begin{array}{c}\text { Active, Student -centred } \\
\text { T\&L Strategies }\end{array}$ & $\begin{array}{c}\text { Design-Led } \\
\text { T\&L Strategies }\end{array}$ \\
\hline GRAFAIC, a bilingual TG APP & $\begin{array}{c}\text { Collaborative Learning (CL) } \\
\text { Model Making }\end{array}$ & $\begin{array}{c}\text { Collaborative Learning } \\
\text { (CL) Table Top }\end{array}$ \\
\hline $\begin{array}{c}\text { ConstrucTec, a CS independent } \\
\text { learning tool for Problem-based } \\
\text { Learning (PBL) }\end{array}$ & $\begin{array}{c}\text { Experiential Active Learning in } \\
\text { CS. }\end{array}$ & $\begin{array}{c}\text { Design-led Multimedia } \\
\text { Pencil Holder }\end{array}$ \\
\hline $\begin{array}{c}\text { Traffic Lights Keyrings for } \\
\text { formative assessment }\end{array}$ & $\begin{array}{c}\text { Peer Presentations on Model } \\
\text { projects in CS }\end{array}$ & Peer Poster Presentations \\
\hline $\begin{array}{c}\text { Augmented Reality tools in CS } \\
\text { Active Experimentation on } \\
\text { timber moisture ratings \& } \\
\text { Student Laboratory Worksheets }\end{array}$ & $\begin{array}{c}\text { Student Design Choice in } \\
\text { Sketching \& Graphic } \\
\text { Design, in TG }\end{array}$ \\
\hline $\begin{array}{c}\text { 'Ticket Out the Door' Exit Card } \\
\text { Platform }\end{array}$ & $\begin{array}{c}\text { Orthographic Projection } \\
\text { preehand Sketching Wall }\end{array}$ & $\begin{array}{c}\text { Board Brainstorming using } \\
\text { Mind maps }\end{array}$ \\
\hline $\begin{array}{c}\text { Incorporating Sign Language as in in TG. } \\
\text { a SEN Strategy }\end{array}$ & 3 D Models in CS & $\begin{array}{c}\text { Student Design Choice in } \\
\text { Model Construction }\end{array}$ \\
\hline
\end{tabular}

Table 2. Data Set 2: Online SP Forum Reflections (2016-2017)

\begin{tabular}{|c|c|c|}
\hline $\begin{array}{c}\text { Creativity \& Innovation } \\
\text { T\&L Strategies }\end{array}$ & $\begin{array}{l}\text { Active, Student -centred } \\
\text { T\&L Strategies }\end{array}$ & $\begin{array}{c}\text { Design-Led } \\
\text { T\&L Strategies }\end{array}$ \\
\hline Sharing Learning Targets (BFK) & Each One Teach One & Design-led Projects \\
\hline Traffic Lights \& AfL (BFK) & Exit Cards & Back to Back \\
\hline $\begin{array}{l}\text { Student Experience Survey } \\
\text { (BFK) }\end{array}$ & Self/Peer Assessment & $\begin{array}{c}\text { Design-led Boat Building } \\
\text { Project }\end{array}$ \\
\hline Learning Ladders (BFK) & AfL Strategies & Design Mood Boards \\
\hline HOPE strategies (BFK) & Collaborative Learning & Peer Board Drawings \\
\hline FIP Strategies (BFK) & Think Pair Share & - \\
\hline $\begin{array}{l}\text { 'Sell Geometry' TED TALK } \\
\text { PBL Activity }\end{array}$ & Peer Demonstrations & - \\
\hline ZPD Grouping & Socratic Method Discussions & - \\
\hline Flipped Classroom & Class Debates & - \\
\hline $\begin{array}{c}\text { Circle explorations: } \\
\text { deconstructing styrofoam spheres }\end{array}$ & Just a Minute & - \\
\hline Consider All Factors & Poster Presentations & - \\
\hline Jigsaw Game & WALT \& WILF Strategies & - \\
\hline $\begin{array}{l}\text { Customised Student-friendly } \\
\text { Technical Assessment Rubrics }\end{array}$ & Peer Presentations & - \\
\hline
\end{tabular}


AIM 2 was to explore the student teacher experience of engagement with innovative teaching practices. This discussion is framed under the headings: formative instructional practices (FIP) and hope strategies, creative assessment strategies, design-led T\&L strategies, creative and innovative strategies in the use of educational technology, and challenges in the implementation of active student-centred T\&L.

\subsection{Formative Instructional Practices \& Hope Strategies}

Formative Instructional Practice (FIP) refers to T\&L strategies promoted by BattelleforKids (BFK) (2016). These are comparable to Assessment for Learning (AfL) strategies promoted in the Irish context (NCCA, 2016). BFK strategies include: clear learning targets, documented evidence of learning, effective feedback, student ownership of their own learning, as well as 'hope' strategies. One practical example of a FIP strategy is the use of a 'traffic lights' system for homework collection and distribution, using red, orange and green coding or cards. One student teacher, who designed traffic lights key rings for students, writes: "I have employed this strategy when collecting assignments in my classes and I believe it to work very well as a non-verbal communication method". Another student aligned BFK 'hope' strategies with John Bigg's Constructive Alignment model, and developed learning targets and learning ladders to enable students to incrementally reach achievable goals and feel the hope of success in the classroom. The student writes: "( $t$ )he class may complete the homework as many times as they like and seek advice for improvement. Thus far, this has improved students' engagement and, more significantly, hope.". Another student similarly links hope to setting out clear learning targets: "(b)y deconstructing and rewriting learning targets in more student friendly language I can help create a more student friendly classroom where students can relate to learning...developing hope". A further hope strategy used by this student in the classroom was a'Ticket Out the Door' exit card strategy, facilitating teacher feedback. Yet another student followed Rosenshine's 'Ten Research-based Principles of Instruction' (Rosenshine, 2012) to proactively promote hope.

\subsection{Creative Assessment Strategies}

Creative examples of formative assessment strategies identified in the data include 'exit cards', 'rubrics' and student-engagement surveys. One student comments: "(e)xit cards allow me to look at the lesson through the eyes of my students". Another student, quoting Walsh \& Dolan (2009, p. 80) writes that "clear rubrics need to be developed that indicate the criteria for success in a particular learning activity. These are used to give the pupils explicit guidelines about teacher expectations". Student surveys, in particular, were found to be effective. One student said: "I intend to use the information gained from student feedback surveys as a platform from which lessons can be developed”. Another student commented that "(t)he exit cards worked very well but the student experience survey 
provided me with much more details on how the students felt in my classes". Another student writes that he modified the lesson structure in response to student surveys, in week six of SP, to help optimize learning. Strategies to empower students to assess their own and others' work are also discussed. One students writes that: "( $\mathrm{t}$ )he act of assessing an object and being able to say 'I could make that!' is a profound experience."

\subsection{Design-led T\&L Strategies}

Examples of learning by design, evidenced in the data, such as the multi-media pencil holder, the boat building project, design mood boards, and design-led projects, is "less about factual content and the mere acquisition of knowledge and more about enabling pupils to understand, think and do things (Robson, 2015, pp. 61-62). This approach has the potential to make the subject more engaging for students and provides for more individual expression. One student, citing Betty Ray (2004) - who correlates design-led T\&L with $21^{\text {st }}$ century skills, such as problem solving, collaboration, and real world solutions - writes:

The majority of my MTW projects have a major amount of design work to them. I feel like by doing more design practical projects it leads to more student engagement with the project as it is their individual work. On reflection I do feel that this style works quite well and I will definitely use it throughout my teaching career.

\subsection{Creative and Innovative Strategies in the Use of Educational Technology}

Particular examples in the data of creativity and innovation in the use of educational technology include: the development of GRAFAIC (a bilingual APP for technical drawing), the development of ConstrucTec (a flipped classroom independent learning tool for construction-related studies), an integrative education boat-building project combining technical subjects, and the invention of a system of whole-class peer teaching of demonstrations in SolidWorks and technical drawings, allowing the teacher to freely monitor learning in the classroom, described as follows:

My thought was to revolve the computer screen at the top of the room to allow students in the front row to use it but I felt the students behind would not be gaining as much as they would not be completing the [SolidWorks] demonstration. I then thought of using a tray with a wireless mouse and keyboard on it... [I am] quite excited to see how well these teaching strategies will work in a future lesson. 


\subsection{Challenges Arising}

An array of active, student centred T\&L strategies were identified in the data (See Tables $1 \& 2)$ and the benefits are discussed above. However, certain challenges and problematics were also identified, including the implementation of innovative practices in traditional settings, where student teachers experienced cultural pressure from teachiung staff to revert to more traditional approaches aligned wuth State examination expectations and demands. The requirement of effective classroom management skills was also identified as a prerequisite for more innovative approaches. One student reflected: "this week I tried to implement an activity called 'Just a Minute' where the students had to research a topic and present it to the class... it was difficult to keep the group on task and as a result the presentations were weak". Another student wrote that when attempting a 'Think Pair Share' activity, it "went horribly wrong". The student continues: "(a)ll I could do was question myself and, if I am honest, active teaching as a whole. Does it really work or is it something which looks great on paper but doesn't actually work inside the classroom"? Apart from classroom management challenges, time management was identified as a further challenge:

...my attempts at creating an active student led classroom can definitely be improved. Last week I attempted to create a student led demonstration in technical graphics... The demonstration took so long that the students hadn't enough time to finish the question themselves which really frustrated me.

\section{Conclusions}

This study examined the extent to which GMIT student teachers demonstrated creativity and innovation in their T\&L strategies while on SP. The study found clear evidence of practices of creativity and innovation in SP as well as a critically reflective and probing implementation of student-centred, active learning and design-led T\&L strategies in the SP classroom. The study identified T\&L inventions, including key ring traffic lights, GRAFAIC (a technical drawing APP) and ContructTec (an interactive PowerPoint tool to promote the flipped classroom in the field of construction studies). BFK FIP strategies were demonstrated, in particular, to have played a significant role in the promotion of effective creative T\&L strategies in SP. Moreover, these strategies were considered instrumental in the promotion of hope in the classroom. The learning impact of such T\&P activities and strategies and implications for reflective practice was the focus of some discussions; one student forum contribution sums this up effectively: “(d)esigning these activities gave me cause to reflect, if no learning takes place then these active learning activities are just activities". Challenges were also identified, including: cultural differences between ITE training and the real world of the classroom, time management challenges, classroom management challenges, and a questioning of the overall value of creative classroom strategies, on the part of one individual who struggled to implement effectively. 


\section{References}

Barrett, T. \& S. Moore. (Eds.) (2011). New Approaches to Problem-based Learning:

Revialising Your Practice in Higher Education. NY: Routledge.

Battelleforkids (2016). Celebrate Teaching. At http://www.celebrateteaching.org/. Accessed 25/04/2017.

Cohen, L., L. Manion \& K. Morrison. Research Methods in Education. $5^{\text {th }}$ Ed.

London: RoutledgeFalmer.

DES (2016) Junior Certificate Materials Technology (Wood) Syllabus. Ireland: Departmen of Education and Skills.

European Commission (2013) Improving the Quality of Teaching and Learning in Europe's Higher Education Institution. High Level Group on the Modernisation of Higher Education: Report to the European Commission. European Union, Belgium. At

http://ec.europa.eu/education/library/reports/modernisation_en.pdf,accessed 30/01/2017.

Flynn, S. (2012) Traditional ways of teaching still prevail. The Irish Times. At

http://www.irishtimes.com/news/traditional-ways-of-teaching-still-prevail-says-study$\underline{1.447178}$, accessed 30/01/2017.

Humphreys, T. (1996). A Different Kind of Teacher: a practical guide to understanding and resolving difficulties within the school. Dublin: Newleaf.

GMIT (2013) Strategic Plan Revision 2013-2016: Strategic Pillars Summary. GMIT.

GMIT (2016) Creativity and Innovation in Teaching. ITE Conference Presentation. At

https://onedrive.live.com/view.aspx?resid=A2C0840CE03D46FA!339\&ithint=file\%2cpp\& app=PowerPoint\&authkey=!AIAV1KLKIDFQL Y , accessed 30/01/2017.

Klopper, C. \& S. Drew. (Eds.) (2015). Teaching for Learning and Learning for Teaching: Peer Review of Teaching in Higher Education. Rotterdam,: Sense Publications.

NCCA (2016) AfL - Key Principles. At

http://www.ncca.ie/en/Curriculum_and_Assessment/Post-

Primary_Education/Junior_CycleAssessment for_Learning_AfL/Key_principles/AfL -_Key_principles.html., accessed 30/01/2017.

Owen-Jackson, G. (Ed.) (2015) Learning to Teach Design and Technology in the Secondary School: A Companion to the school experience. $3^{\text {rd }}$ Ed. NY: Routledge.

Partnership Management Board, The. (2007) Active Learning and Teaching Methods for Key Stage 3. Northern Ireland: PMB Publication.

Quinn, R.E., K. Heynoski, M. Thomas \& G.M. Spreitzer. The Best Teacher in You: How to Accelerate Learning and Change Lives. San Francisco:BK Publ. Inc.

Renville, W. (2015) The reason why modern teaching methods don't work. The Irish

Times. At http://www.irishtimes.com/news/science/the-reason-why-modern-teachingmethods-don-t-work-1.2115219, accessed 30/01/2017.

Rosenshine, B. (2012) Principles of Instruction. Research-based Strategies that All 
Logue, P. A.

Teachers Should Know. American Educator, pp. 12-39. At https://www.aft.org/sites/default/files/periodicals/Rosenshine.pdf, accessed 30/01/2017.

Walsh, B. \& R. Dolan. (2009). A Guide to Teaching Practice in Ireland. Dublin: Gill \& Macmillan. 